\title{
PEREMPUAN PENGEMUDI GO-JEK DI JEMBER
}

\author{
Veni Verantika Eka Rahayu ${ }^{1}$, Sukidin ${ }^{1}$, Pudjo Suharso ${ }^{1}$ \\ ${ }^{1}$ Pendidikan Ekonomi, Fakultas Keguruan dan Ilmu Pendidikan, Universitas Jember \\ E-mail: veniverantika44@gmail.com
}

\begin{abstract}
Abstrak
Penelitian ini bertujuan untuk mendeskripsikan motivasi, curahan waktu kerja dan risiko yang dialami perempuan pengemudi go-jek di Jember. Penelitian ini merupakan penelitian yang menggunakan metode deskriptif dengan pendekatan kualitatif. Subjek dalam penelitian ini yaitu perempuan pengemudi go-jek di Jember. Metode pengumpulan data dalam penelitian ini menggunakan metode wawancara, observasi, dan dokumen. Analisis data menggunakan tiga kegiatan, yaitu reduksi data, penyajian data, dan pemaparan kesimpulan. Hasil penelitian ini menunjukkan bahwa perempuan yang bekerja sebagai pengemudi go-jek di Jember, karena adanya berbagai motivasi yang juga dipengaruhi oleh perbedaan status. Perempuan pengemudi go-jek yang telah berkeluarga memiliki motivasi ingin memperoleh pendapatan sendiri, dan membantu suami mencari nafkah untuk keluarga. Selain itu, perempuan single parent yang bekerja sebagai pengemudi go-jek, karena memiliki tanggung jawab untuk memenuhi kebutuhan keluarga dan perempuan yang belum menikah memutuskan bekerja sebagai pengemudi go-jek, karena ingin mandiri dan menambah teman. Curahan waktu kerja perempuan pengemudi go-jek di Jember rata-rata sekitar 7 sampai 8 jam sehari. Adapula risiko yang pernah dialami, yaitu menghadapi konsumen yang terkadang marah, karena tidak puas dengan pelayanannya, pembatalan dari konsumen, ban sepada motor bocor dan kecelakaan.
\end{abstract}

Kata Kunci: Motivasi, Curahan Waktu Kerja, Risiko, Perempuan Pengemudi Go-jek.

\section{PENDAHULUAN}

Perkembangan transportasi darat di Indonesia terus berevolusi, dengan adanya perubahan yang terjadi sedikit demi sedikit. Tranportasi darat di Indonesia dulunya adalah transportasi tradisional yang menggunakan tenaga manusia atau hewan, seperti becak, sepeda kayuh, dan delman. Seiring dengan perkembangan teknologi transportasi, mampu menghadirkan transportasi baru berupa kendaraan yang digerakkan oleh mesin. Kini, transportasi yang menggunakan tenaga mesin menjadi transportasi yang digunakan oleh sebagian besar masyarakat Indonesia untuk melalukan mobilitas, transportasi darat yang menggunakan tenaga mesin ini seperti, ojek sepeda motor, taksi, bis, dan kereta api.

Perkembangan layanan transportasi kini semakin maju, dengan memanfaatkan teknologi informasi dan komunikasi yang menghadirkan inovasi baru berupa transportasi online berbasis aplikasi. Salah satu perusahaan layanan transportasi online di Indonesia adalah PT Aplikasi Karya Anak Bangsa yang dikenal dengan go-jek. Pada tahun 2011 go-jek mulai merintis usahanya dalam bidang penyediaan layanan transportasi berupa ojek. Pada awalnya go-jek masih menggunakan call center untuk menghubungkan pengemudi go-jek dengan penumpang, kemudian dikembangkan menjadi layanan ojek berbasis aplikasi yang dapat dipasang di ponsel android. Peluncuran aplikasi gojek di mulai pada awal tahun 2015, aplikasi tersebut sebagai pengganti sistem pemesanan sebelumnya yang menggunkan call center (Krisno, 2017, dalam Inet.detik.com).

Bekerja sebagai pengemudi go-jek dianggap sebagai pekerjaan yang maskulin, yang pada umum dilakukan oleh kaum laki - laki, karena pekerjaan sebagai pengemudi go-jek merupakan pekerjaan yang berisiko, seperti kecelakaan. Menurut Suyanto dan Hendrarso (1999 : 165) kini perempuan mulai memasuki ke sektor-sektor yang semulanya hanya didominasi oleh kaum laki laki. Selain itu, pekerjaan sebagai pengemudi go-jek merupakan suatu pekerjaan yang membutuhkan tenaga, waluapun pekerjaan sebagai pengemudi go-jek merupakan pekerjaan yang berisiko, membutuhkan tenaga dan didominasi oleh kaum laki-laki, tetapi hal tersebut tidak menjadi penghalang bagi kaum perempuan untuk bekerja sebagai pengemudi go-jek.

Perempuan yang bekerja sebagai pengemudi go-jek menunjukkan bahwa perempuan memiliki hak yang setara dengan laki-laki dalam berbagai bidang terutama dalam bidang pekerjaan. Menurut Naila Kabeer (dalam Eriyanti dkk, 2013 : 74) perempuan memiliki hak yang sama dengan kaum laki- 
laki yang mencakup partisipasi ekonomi, pencapaian pendidikan, kesehatan, kesejahteraan, pekerjaan, dan semua layanan publik yang setara dengan laki-laki. Berdasarkan hasil wawancara dengan ketua komunitas perempuan pengemudi go-jek di Jember menyatakan bahwa jumlah perempuan pengemudi gojek di Jember terus meningkat dalam tiga tahun terakhir. Peningkatan tersebut menunjukkah bahwa partisipasi perempuan yang bekerja sebagai pengemudi go-jek cukup besar.

Sebagian perempuan memutuskan untuk bekerja sebagai pengemudi, karena adanya motivasi yang berasal dari diri sendiri maupun dari lingkungan sekitar untuk mencapai tujuan. Menurut Gray (dalam Hamali, 2016 : 130 - 131) motivasi sebagai hasil dari sejumlah proses yang bersifat internal dan eksternal bagi seseorang yang menyebabkan timbulnya sikap antusiasme dalam melaksanakan kegiatan-kegiatan tertentu. Perempuan yang bekerja sebagai pengemudi go-jek dianggap sebagai perempuan-perempuan yang tangguh, karena mereka harus menghabiskan sebagian waktu mereka di jalanan untuk mengantar penumpang, mengantar pesanan makanan maupun mengantar pesanan belanja yang dipesan oleh pelanggan melalui aplikasi go-jek.

Salah satu alasan perempuan memilih bekerja sebagai pengemudi go-jek, karena waktu kerjanya yang tidak terikat, sehingga pembagian dan penggunaan waktu kerja sepenuhnya diatur oleh pengemudi go-jek. Berdasarkan observasi awal, peneliti dapat menjumpai perempuan pengemudi gojek di sekitar kampus Universitas Jember yang melayani pemesanan jasanya pada pagi hari, siang, sore bahkan malam hari. Hal tersebut menunjukkan bahwa perempuan yang bekerja sebagai pengemudi g-ojek harus menghabiskan sebagian waktunya di jalanan untuk melayani konsumen, bahkan mereka bekerja sampai malam hari. Selain itu, perempuan pengemudi go-jek juga harus membagi waktunya untuk menyelesaikan kegiatan sehari-hari di rumah, di lingkungan masyarakat, dan kegiatan personal lainnya.

Berdasarkan latar belakang yang telah diuraikan diatas, tentang fenomena perempuan yang bekerja sebagai pengemudi go-jek di Jember, yang mana pekerjaan tersebut didominasi oleh kaum laki-laki dan memiliki berbagai resiko, tetapi hal itu tidak menjadi penghalang bagi perempuan untuk bekerja sebagai pengemudi go-jek. Adanya fenomena tersebut, peneliti bermaksud mengadakan penelitian yang berjudul "Perempuan Pengemudi Go-jek di Jember".

\section{METODE PENELITIAN}

Penelitian ini merupakan penelitian yang menggunakan metode deskriptif dengan pendekatan kualitatif. Lokasi penelitian ini dilaksanakan di sekitar kampus Universitas Jember. Penentuan lokasi penelitian ini sesuai dengan fenomena yang terjadi di lapangan, dimana peneliti dapat menjumpai perempuan pengemudi gojek yang menjalankan pekerjaannya di sekitar kampus Universitas Jember. Subjek dalam penelitian ini adalah perempuan pengemudi gojek yang di jumpai di sekitar kampus Universitas Jember. Metode pengumpulan data yang digunakan terdiri dari metode wawancara, observasi, dan dokumen. Analisis data yang digunakan yaitu reduksi data, penyajian data, dan pemaparan kesimpulan.

\section{HASIL DAN PEMBAHASAN \\ Hasil Penelitian}

Perempuan yang bekerja sebagai pengemudi gojek memiliki motivasi yang berbeda, yaitu kebutuhan fisiologis, kebutuhan rasa aman, kebutuhan sosial, kebutuhan harga diri, dan aktualisasi diri. Hal ini dikarenakan perbedaan status perempuan pengemudi go-jek di Jember, yaitu berkeluarga, single parent, dan lajang/belum menikah. Perbedaan status tersebut juga mempengaruhi waktu kerja yang digunakan perempuan pengemudi go-jek, yaitu berkaitan dengan waktu mulai bekerja dan menyelesaikan pekerjaannya. Rata-rata curahan waktu kerja yang digunakan perempuan pengemudi go-jek di Jember, yaitu 7 sampai 8 jam per hari. Adapun risiko yang pernah dialami perempuan pengemudi go-jek di Jember, yaitu harus menghadapi konsumen yang terkadang marah, karena tidak puas dengan pelayanannya, pembatalan yang dilakukan oleh konsumen, ban sepeda bocor dan kecelakaan. 


\section{Motivasi Kerja Perempuan Bekerja Sebagai Pengemudi Go-jek}

Bagi seorang perempuan yang telah menikah dan bekerja sebagai pengemudi go-jek sematamata membantu suami mencari nafkah untuk memenuhi kebutuhan fisiologis keluarga, atau untuk meningkatkan ekonomi keluarga, sehingga hal ini juga menyebabkan seorang istri memutuskan untuk bekerja. Selain itu, alasan perempuan bekerja sebagai pengemudi go-jek untuk keberlangsungan hidupnya, terutama bagi perempuan single parent yang harus menjadi tulang punggung keluarga dalam mencari nafkah untuk memenuhi kebutuhan sehari-hari. Bagi seorang ibu yang mencari nafkah seorang diri akan mempertimbangkan pendapatan yang diperolehnya dalam bekerja, karena pendapatan tersebut nantinya akan digunakan untuk memenuhi segala kebutuhan hidupnya. Hal ini dijelaskan oleh SN $39^{\mathrm{Th}}$ yang bekerja sebagai pengemudi go-jek, karena pendapatan yang diperoleh lebih besar dari sebelumnya, yaitu sebesar Rp.150.000,00 - Rp.170.000,00 dalam sehari, sedangkan pendapatan yang diperoleh sebelumnya sebesar Rp.1.200.000,00 dalam per bulan. Pendapatan yang diperoleh nantinya digunakan untuk memenuhi berbagai kebutuhan, seperti makan, membayar tagihan air dan listrik, serta pakaian.

Setiap perempuan pengemudi go-jek keamanan dalam bekerja sangat diperlukan untuk memastikan keselamatan dalam melakasanakan pekerjaannya. Perusahaan go-jek memiliki wewenang dalam memberikan jaminan keamanan atau keselamatan kepada setiap pengemudi go-jek. Perusahaan go-jek telah meluncurkan aplikasi untuk pengemuudi dan konsumen go-jek pada tahun 2015 lalu. Aplikasi tersebut terus dikembangkan untuk bisa menunjang kenyamanan pengemudi dan konsumen, yang juga dilengkapi dengan GPS yang dapat mendeteksi lokasi pengemudi maupun penumpang. Adanya aplikasi tersebut memberikan dampak positif bagi perempuan pengemudi go-jek yang dapat berbagi lokasi kepada komunitasnya yang bertunjuan untuk mengantisipasi risiko di jalan dan perempuan pengemudi gojek lebih merasa aman dalam menjalankan pekerjaannya. Selain itu, jaminan keselamatan yang diberikan perusahaan go-jek kepada pengemudi berupa BPJS ketenagakerjaan guna menunjang keselamatan dan keamanan pengemudi dalam bekerja, dan pengarahan kepada pengemudi go-jek mengenai hal-hal yang harus diperhatikan untuk menunjang keamanan dalam bekerja, seperti penggunaan atribut dan helm dalam berkendara.

Sebagian perempuan yang bekerja sebagai pengemudi go-jek menyukai pekerjaannya, karena mereka dapat berinteraksi dengan lebih banyak orang dan bisa menjalin pertemanan dengan mudah, terutama dengan sesama pengemudi go-jek. Adanya jalinan pertemanan antara pengemudi go-jek membuat para pengemudi go-jek merasa nyaman dalam menjalani pekerjaannya. Persaingan diantara mereka ditentukan berdasarkan sistem, sehingga tidak berebut untuk memperoleh penumpang, tetapi setiap pengemudi go-jek berkompetisi untuk melakukan layanan terbaik kepada konsumen agar penilaian yang diberikan oleh konsumen tetap tinggi. Selain itu, perempuan pengemudi go-jek yang telah tutup poin akan segera menyelesaikan pekerjaannya, sehingga akan memberikan peluang bagi pengemudi go-jek yang lain untuk memperoleh penumpang. Adanya suatu komunitas pengemudi gojek sebagai wadah untuk mempererat dalam menjalin pertemanan antar perempuan pengemudi go-jek, dan bergabungnya di suatu komunitas atau grup tertentu merupakan bentuk kesadaran bagi setiap perempuan pengemudi go-jek, bahwa dalam menjalankan pekerjaannya akan membutuhkan teman sesama grup untuk membantunya ketika menghadapi sesuatu di jalan.

Setiap perempuan yang berstatus menikah, single parent, dan lajang/ belum menikah dalam bekerja memiliki motivasi yang berbeda-beda, ada pula perempuan bekerja karena ingin dihargai bahwa seorang perempuan juga dapat bekerja dan dapat menyelesaikan pekerjaannya dengan baik. Kebebasan perempuan dalam memperoleh haknya yaitu dengan bekerja membuat mereka lebih mandiri dalam memenuhi kebutuhannya sendiri dengan menggunakan pendapatan yang diperolehnya dari bekerja. Selain itu, dengan bekerja perempuan juga memiliki wewenang dalam mengatur keuangannya sendiri. Seorang ibu single parent ingin memenuhi tanggung jawabnya sebagai orang tua dalam memenuhi kebutuhan keluarga, dengan bekerja sebagai pengemudi go-jek seorang ibu single parent merasa dapat mencukupi segala kebutuhan keluarganya dengan pendapatan yang diperoleh.

Bagi seorang perempuan bekerja bukan hanya untuk memenuhi kebutuhan secara finansial, tetapi sebagian perempuan bekerja karena ingin mengembangkan potensi yang dimiliki. Bekerja 
sebagai pengemudi go-jek merupakan sarana untuk mengembangkan kemampuan dalam berkomunikasi, karena tuntutan dari go-jek yang mengharuskan setiap pengemudi go-jek untuk melayani konsumennya dengan ramah. Hal ini, dapat melatih kemampuan berkomunikasi perempuan pengemudi go-jek dalam setiap pelayanannya kepada konsumen. Perempuan memilih bekerja sebagai pengemudi go-jek juga karena mereka memiliki kemampuan dalam mengendarai sepeda motor dan memiliki keinginan untuk menggunakan kemampuannya tersebut untuk memperoleh pendapatan dengan bekerja.

\section{Curahan Waktu Kerja Perempuan Pengemudi Go-jek}

Perempuan yang bekerja sebagai pengemudi go-jek memiliki waktu kerja yang dapat ditentukan sendiri, dari jam mereka memulai bekerja maupun jam dimana mereka menyelesaikan pekerjaannya. Waktu kerja yang tidak terikat membuat perempuan pengemudi go-jek lebih leluasa dalam mengatur waktunya, yaitu waktu dalam menyelesaikan pekerjaan rumah, menjalankan kegiatan di masyarakat maupun kegiatan pribadi dan mengatur waktu kerja yang sesuai dengan keinginnya. Perempuan pengemudi go-jek lebih bebas dalam menentukan berapa lama waktu kerja yang digunakan, kapan mereka memulai bekerja, dan meyelesaikan pekerjaannya.

Berdasarkan hasil penelitian bahwa curahan waktu kerja perempuan pengemudi go-jek di Jember berbeda-beda, mereka yang memiliki anak usia sekolah akan memulai pekerjaannya setelah mengantarkan anaknya ke sekolah, dan akan menonaktifkan aplikasinya ketika mendekati waktu pulang sekolah, karena mereka akan menjemput anaknya di sekolah dan mengantarkannya pulang. Adapula yang bekerja setelah menyelesaikan pekerjaan rumah, seperti memasak, mencuci dan membersihkan rumah. Waktu selesai bekerja perempuan pengemudi go-jek juga berbeda, ada yang menyelesaikan pekerjaannya pada sore hari dan yang menyelesaikan pada malam hari. Hal ini sesuai dengan pilihan waktu kerja perempuan pengemudi go-jek berbea-beda, karena mereka memiliki kegiatan sehari-hari yang berbeda. Perbedaan waktu kerja tersebut juga dipengaruhi oleh poin yang telah dicapai, jika telah mencapai tutup poin maka mereka akan segera menyelesaikan pekerjaannya. Rata-rata curahan waktu kerja perempuan pengemudi go-jek di Jember berkisar antara 7-8 jam per hari.

\section{Risiko Yang Dihadapi Perempuan Pengemudi Go-jek}

Setiap pekerjaan memiliki tantangan tersendiri, begitu juga bekerja sebagai pengemudi go-jek yang kesehariannya bekerja di jalanan tentunya memiliki tantangan tersendiri dalam menjalankkannya, terutama bagi perempuan yang bekerja sebagai pengemudi go-jek yang harus menghadapi berbagai tantangan ketika bekerja. Beragam karakter konsumen menjadi salah satu tantangan yang seringkali dihadapi oleh perempuan pengemudi go-jek, mulai dari konsumen yang mempermasalahkan pelayanan dan bahkan mendapatkan penilaian yang rendah dari konsumen. Bagi perempuan pengemudi go-jek dalam menghadapi konsumen terkadang lebih sulit dibandingakan dengan pengemudi go-jek laki-laki, karena seringkali perempuan pengemudi go-jek menerima pembatalan dari penumpang ketika mengetahui bahwa pengemudi seorang perempuan.

Selain itu, perempuan pengemudi go-jek juga harus menghadapi konsumen yang tidak bertanggung jawab, yang terkadang melakukan penipuan dalam pemesanan layanan go-jek. Hal ini menjadi salah satu risiko yang merugikan bagi perempuan pengemudi go-jek, kerena mereka harus menanggung kerugian barang yang telah dibeli jika konsumen melakukan pemesanan palsu pada layanan go-food maupun go-shop. Perempuan yang bekerja sebagai pengemudi go-jek harus menghadapi risiko di jalanan, karena keseharian mereka bekerja di jalanan untuk menjemput dan mengantar penumpang ke tempat tujuan, sehingga hal ini menyebabkan mereka harus siap menghadapi risiko di jalan, seperti risiko terjadinya kecelakaan, dan risiko terjadinya ban bocor di jalan.

\section{Pembahasan}

Berdasarkan penelitian yang telah dilakukan dapat diketahui bahwa motivasi perempuan bekerja sebagai pengemudi go-jek di Jember merupakan dorongan yang berasal dari dalam diri perempuan itu sendiri maupun dari luar yang dapat mempengaruhi seseorang melakukan sesuatu 
dengan tujuan tertentu. Adanya tujuan yang ingin dicapai menyebabkan perempuan memutuskan untuk bekerja sebagai pengemudi go-jek. Hal ini sesuai dengan pendapat Gray (dalam Hamali, 2016 : 130 - 131) yang menyatakan bahwa motivasi sebagai hasil dari sejumlah proses yang bersifat internal dan eksternal bagi seseorang yang menyebabkan timbulnya sikap antusiasme dalam melaksanakan kegiatan-kegiatan tertentu. Berbagai motivasi yang mendorong perempuan untuk bekerja sebagai pengemudi go-jek untuk mencapai tujuan yang diinginkan membuat perempuan memiliki semangat bekerja agar dapat mencapai tujuan tersebut.

Adapun motivasi perempuan pengemudi go-jek di Jember, yaitu perempuan yang telah menikah dan bekerja untuk memperoleh pendapatan sendiri tanpa selalu bergantung pada suami dan meningkatkan ekonomi keluarga. Perempuan bekerja juga untuk memenuhi kebutuhan fisiologis, seperti perempuan single parent yang mencari nafkah untuk memenuhi kebutuhan anak-anaknya. Selain itu, perempuan pengemudi go-jek juga membutuhkan rasa aman dalam menjalankan pekerjaannya, dan mereka juga bergabung dengan salah satu grup untuk saling membantu dalam bekerja. Perempuan yang bekerja sebagai pengemudi go-jek juga dapat mengembangkan potensi diri yang dimiliki serta menggunakan kemampuan mengendarai sepeda motor untuk bekerja dan memperoleh pendapatan. Hal ini sesuai dengan sesuai dengan pendapat maslow (dalam Sedarmayanti, 2017: 155) tentang hierarki kebutuhan manusia yang berjenjang, kebutuhan fisiologis menjadi kebutuhan paling dasar, setelah kebutuhan fisiologis terpenuhi akan muncul kebutuhan selanjutnya yaitu kebutuhan rasa aman. Setelah kebutuhan fisiologis dan rasa aman terpenuhi, pada tingkat ketiga akan muncul kebutuhan sosial, tingkat keempat kebutuhan harga diri dan kebutuhan tingkat tertinggi aktualisasi diri.

Bekerja sebagai pengemudi go-jek merupakan pekerjaan yang waktu kerjanya tidak terikat, sehingga bagi perempuan yang bekerja sebagai pengemudi go-jek di Jember memiliki kewenangan sendiri dalam mengatur waktunya baik dalam bekerja maupun waktu untuk kegiatan yang lainnya. Berdasarkan data yang diperoleh peneliti dilapangan menunjukkan bahwa penggunaan waktu kerja mayoritas perempuan pengemudi go-jek di Jember adalah 7 sampai 8 jam per hari kerja. Hal ini sesuai dengan waktu kerja yang digunakan di Indonesia yang tertulis pada Undang-Undang Republik Indonesia Nomor 13 Tahun 2003 Tentang Ketenagakerjaan yang dijelaskan pada pasal 77 bahwa ketentuan waktu kerja adalah 7 jam 1 hari dan 40 jam 1 minggu untuk 6 hari kerja dalam 1 minggu; atau 8 jam 1 hari dan 40 jam 1 minggu untuk 5 hari kerja dalam 1 minggu. Walaupun pekerjaan sebagai pengemudi go-jek memiliki waktu kerja yang tidak terikat, tetapi waktu kerja yang digunakan perempuan pengemudi go-jek dalam per hari kerja seseuai dengan ketentuan waktu kerja yang diatur dalam Undang-Undang Republik Indonesia yaitu 7 sampai 8 jam.

Berdasarkan hasil penelitian dapat diketahui bahwa setiap perempuan yang bekerja sebagai pengemudi go-jek memiliki cara tersendiri dalam membagi waktunya, yang mana mereka memiliki kegiatan yang berbeda, sehingga dalam penggunaan waktu kerja beberapa perempuan pengemudi gojek juga berbeda. Hal ini sesuai dengan pendapat Sumarsono (2003 : 30) yang menyatakan bahwa curahan jam kerja yang digunakan setiap individu dalam per minggu tidaklah sama, setiap individu memiliki waktu kerja yang berbeda-beda sesuai dengan dimana mereka bekerja. Perbedaan pembagian waktu perempuan pengemudi go-jek disebabkan karena waktu kerja di go-jek yang tidak terikat, dan kegiatan sehari-hari yang dilakukan perempuan pengemudi yang berbeda, walaupun penentuan waktu kerjanya berbeda tetapi rata-rata curahan waktu kerja yang digunakan perempuan pengemudi go-jek adalah 7 sampai 8 jam setiap kali kerja.

Berdasarkan wawancara dengan informan penelitian, beberapa perempuan pengemudi go-jek pernah mengalami kecelakaan dan ban sepeda motor bocor. Selain itu, perempuan pengemudi go-jek di Jember juga di hadapkan dengan berbagai risiko yang lain, seperti menghadapi konsumen pemarah, melakukan pembatalan sepihak, dan penipuan dalam pemesanan layanananya. Hal tersebut dapat terjadi tanpa disangka-sangka dan bisa saja dialami oleh perempuan pengemudi go-jek dalam menjalankan pekerjaannya. Hal ini sesuai dengan pendapat Joel Bessis (dalam Mulyawan, 2015 : 29) yang menyatakan bahwa risiko ketidakpastian karena adanya perubahan atau suatu penyimpangan dari yang diharapkan, sehingga faktor ketidakpastian ini dapat menyebabkan timbulnya risiko pada suatu kegiatan. 
Risiko yang dialami perempuan pengemudi go-jek, tentunya membawa dampak tersendiri yang dapat menyebabkan kerugian, seperti kecelakaan yang pernah dialami Yuliatin menyebabkan kerusakan pada sepeda motornya dan kerugian akibat membayar ganti rugi kepada supir angkot. Selain itu, perempuan pengemudi go-jek terkadang juga mendapat pesanan fiktif dari konsumen, yang mana hal tersebut tentunya dapat merugikan pengemudi go-jek karena barang yang telah dibeli oleh pengemudi go-jek tidak dibayar oleh konsumen. Hal tersebut sejalan dengan pendapat Rustam (2017 : 5) bahwa risiko merupakan potensi kerugian akibat terjadinya suatu peristiwa tertentu dan kemungkinan dapat menyebabkan kerugian jika tidak diantisipasi. Oleh karena itu, perempuan pengemudi go-jek perlu mengantisipasi terjadinya suatu risiko, yaitu harus berhati-hati dalam berkendara dengan menggunakan helm untuk kemanan dan mematuhi peraturan lalu lintas yang ada. Selain itu, perempuan pengemudi go-jek juga harus berhati-hati dalam menerima pesanan dari konsumen, dan diusahakan untuk mengonfirmasi ulang pesanan konsumen

\section{PENUTUP}

Berdasarkan hasil dan pembahasan yang telah dipaparkan diatas dapat disimpulkan bahwa motivasi perempuan pengemudi go-jek yaitu, 1) pemenuhan kebutuhan fisiologis sebagai pendorong untuk memperoleh pendapatan demi memenuhi kebutuhan keluarga. 2) Kebutuhan rasa aman dalam menjalankan pekerjaannya sebagai pengemudi go-jek. 3) Kebutuhan sosial sebagai pendorong dalam menjalin pertemanan dan diterima di lingkungan kerja atau kelompok tertentu. 4) Kebutuhan harga diri sebagai pendorong untuk mengukuhkan kemandirian seorang perempuan, dan menunjukkan bahwa perempuan mampu bertanggung jawab dan bekerja pada sektor yang didominasi oleh kaum laki-laki. 5) Aktualisasi diri sebagai pengembangan diri bagi perempuan pengemudi go-jek dan menggunakan kemampuan yang dimiliki dalam bekerja. Berbagai motivasi tersebut mendorong perempuan memutuskan untuk bekerja sebagai pengemudi go-jek.

Perempuan yang bekerja sebagai pengemudi go-jek di Jember rata-rata curahan waktu yang digunakan untuk bekerja sekitar 7 sampai 8 jam setiap kali bekerja dalam seminggu, waktu tersebut ditentukan sesuai dengan kegiatan sehari-hari yang dilakukan oleh pengemudi go-jek atau sesuai dengan target kerja yang ingin dicapai. Selain itu, perempuan yang bekerja sebagai pengemudi go-jek juga dihadapkan dengan berbagai risiko dalam menjalankan pekerjaannya yaitu, menghadapi konsumen pemarah, pembatalan pemesanan, penipuan dalam pemesanan layanan go-jek, mengalami ban bocor dan kecelakaan di jalan. Berbagai risiko tersebut dapat dialami oleh setiap pengemudi gojek dalam menjalankan pekerjaannya.

\section{DAFTAR PUSTAKA}

Eriyanti, L. D., M. Nurhasan, dan D. Susilo. 2013. Perempuan Buruh Perkebunan. Subang: Deka Publishing

Hamali, A. Y. 2016. Pemahaman Sumber Daya Manusia. Yogyakarta: CAPS

Mulyawan, S. 2015. Manajemen Risiko. Bandung: Cv Pustaka Setia

Rustam, B.R. 2017. Manajemen Risiko: Prinsip, Penerapan dan Penelitian. Jakarta: Salemba Empat

Sedarmayanti. 2017. Perencanaan dan Pengembangan Sumber Daya Manusia Untuk Meningkatkan Kompetensi, Kinerja, dan Produktivitas Kerja. Bandung : Refika Aditama

Sumarsono, S. 2003. Ekonomi Manajemen Sumberdaya Manusia dan Ketenagakerjaan. Yogyakarta: Graha Ilmu

Suyanto, B., dan E. S. Hendrarso. 1996. Wanita Dari Subordinasi Dan Marginalisasi Menuju Ke Pemberdayaan. Surabaya: Airlangga University Press 